The physiological role of the pro-myelocytic leukaemia (PML) gene product is poorly defined. Among other functions, PML is involved in haematopoietic differentiation and in control of cell growth and tumorigenesis. We investigated the regulation of human PML expression by in terferons (IFNs) and IL-1 in various human haematopoietic lines (U937, THP1, HL60, NB4), in human diploid fibroblasts and in human peripheral blood leukocytes. Cytokineinduced modulation of PML expression was assessed by Northern blot analyses, flow cytometry studies and in situ im munolabelling. Our data show that IFNs and IL-1 upregulate PML transcript and protein expression in a time and dose-dependent manner. In situ immunolabelling revealed that upregulation of protein expression by IFN- $\alpha$ is a consequence of a marked increase in both the number and the intensity of the staining of so-called PML nuclear bodies. Our data suggest that stimulation of PML expression by interferons and IL-1 may account for upregulation of PML protein s observed in inflam matory tissues and in proliferative states.

Key words: PML, Interferons, IL-1

\section{Induction of the pro-myelocytic leukaemia gene by type I and type II interferons}

\author{
M. Heuser, ${ }^{1}$ H. van der Kuip, ${ }^{1}$ B. Falini, ${ }^{2}$ C. Peschel, ${ }^{1}$ \\ C. Huber ${ }^{1}$ and T. Fischer ${ }^{1, C A}$
}

${ }^{1}$ III. Medical Department, Johannes-GutenbergUniversity Mainz, Langenbeckstr. 1, 55131 Mainz, Germany; ${ }^{2}$ stituto Clinica Medica I, University of Perugia, Policlinico, Monteluce, 06100 Perugia, Italy

\author{
${ }^{\mathrm{CA}}$ Corresponding Author \\ Tel: (+49) 6131176544 \\ Fax: (+49) 6131176678 \\ Email: t.fischer@3-med.klinik.uni-mainz.de
}

\section{Introduction}

The PML (pro-myelocytic leukaemia) gene was identified originally as a fusion partner of the RAR $\alpha$ gene in the chromosomal translocation $\mathrm{t}(15 ; 17)$ specific for acute promyelocytic leukaemia (APL).$^{1-4}$ Several PMLcDNAs have been isolated, resulting from alternative RNA splicing in the $3^{\prime}$ coding region of a single gene. ${ }^{5}$ The encoded proteins have a predicted molecular weight ranging from 47 to $98 \mathrm{kDa}$. PML proteins belong to a heterogeneous family of DNA-binding proteins characterized by the $\mathrm{C}_{3} \mathrm{HC}_{4}$ zinc binding ring finger. PML protein expression features a typical speckled nuclear pattern which is the consequence of the localization of the protein in nuclear compartments named nuclear bodies. ${ }^{2}$ The function of the PML nuclear bodies is still unknown. Recently it has been shown that PML participates in regulation of haematopoietic differentiation and in control of cell growth and tumorigenesis. ${ }^{6}$ In addition, there is evidence that PML protein is aberrantly expressed in a variety of pathological conditions including malignancies. ${ }^{7,8}$ The level of PML expression is upregulated in inflammatory tissues and in benign or malignant proliferative states. $^{7-9}$ Cytokines, especially interferons (IFNs), are likely to represent some of the mediators that may be involved in overexpression of PML under these circumstances. Interferons are polypeptides that mediate pleiotropic effects on sensitive cells (reviewed in Sen and Lengyel ${ }^{10}$ ). Major activities of IFNs include immunomodulating activ- ities, antiviral effects and inhibition of cellular grow th. Two families of IFNs can be distinguished: type I IFNs (IFN- $\alpha / \beta$ and IFN- $\omega$ ) and type II IFN $(\gamma)$. Type I IFNs are encoded by a family of over 20 genes, whereas type II IFN is structurally unrelated and encoded by a single gene. ${ }^{10} \mathrm{An}$ important function of IFNs is regulation of cellular grow th of normal and malignant cells. The molecular mechanisms involved in grow th inhibition are poorly understood.

Here, we investigated modulation of PML expression by interferons, TNF- $\alpha$ and IL-1. We present evidence that PML gene expression is enhanced by type I and type II interferons and by IL-1. We analysed cytokine induced up-regulation of PML transcript and protein expression in human haematopoietic cell lines, in human diploid fibroblasts and in human peripheral blood leukocytes. Modulation of PML protein expression by IFN- $\alpha$ and IL-1 was assessed with immunofluorescence flow cytometry. Immunofluorescence in situ analysis of PML nuclear bodies revealed that IFN treatment resulted in up-regulation of both the intensity and the number of these nuclear structures.

\section{Materials and methods}

\section{Cell culture and materials}

HL60, NB4, U937 and THP1 cells were obtained from the American Type Culture Collection (Rockville, MD, USA). Peripheral blood mononuclear cells (PBMNC) 
were isolated from heparinized venous blood from normal donors by Fioll-Hypaque (Lymphoprep, Nyegaard, Norway) density separation as described. ${ }^{11}$ Human diploid foreskin fibroblasts were obtained from the Department of Dermatology, University of Mainz, Germany. All cells were grown in RPMI 1640 (Seromed, Munich, Germany) supplemented with $10 \%$ fetal calf serum (PAA, Cölbe, Germany), penicillin $50 \mathrm{IU} / \mathrm{ml}$ (Serva, Heidelberg, Ge rmany), streptomycin $50 \mathrm{IU} / \mathrm{ml}$ (Serva), sodiumpyruvate $1 \mathrm{nmol} / \mathrm{l}$, L-glutamine $2 \mathrm{mmol} / \mathrm{l}$ (Seromed), L-asparagine $20 \mu \mathrm{g} / \mathrm{ml}$ (Boehringer, Mannheim, Germany), 2-mercaptoethanol $0.05 \mathrm{mmol} / \mathrm{l}$, HEPES $10 \mathrm{mmol} / \mathrm{l}$, and nonessential aminoacids (Seromed) at $37^{\circ} \mathrm{C}$ and $5 \%$ $\mathrm{CO}_{2}$ as described. ${ }^{11}$

rh-IFN- $\alpha 2 \mathrm{~b}$ with a specific activity of $1.8 \times 10^{8} \mathrm{IU} /$ mg was obtained from Essex Pharma (Munich, Germany). h-IFN- $\gamma$ w as purchased from Thomae (Biberach, Germany). rh-IL-1 $\alpha$ was kindly provided by Hoffmann La Roche (Nutley, NJ), rh-TNF- $\alpha\left(6.6 \times 10^{6} \mathrm{IU} / \mathrm{mg}\right)$ by Knoll AG (Ludw igshafen, Germany) and rh-IFN- $\beta$ ( $3 \times$ $10^{8} \mathrm{IU} / \mathrm{mg}$ ) by Bioferon (Laupheim, Germany).

\section{Northern blot analysis}

Total RNA was isolated by the method of Chomczynski and Sacchi ${ }^{12}$ and Northern blot analysis was performed essentially as described. ${ }^{11}$ RNA $(20 \mu \mathrm{g})$ was subjected to electrophoresis on a $1 \%$ formaldehyde agarose gel and transferred to nylon membranes (Hybond N, Amersham Buchler, Braunschweig, Germany). All hybridizations were carried out at $65^{\circ} \mathrm{C}$ for $16 \mathrm{~h}$ in a solution containing $1 \% \mathrm{BSA}, 7 \%$ SDS, $1 \mathrm{mM}$ EDTA, and $0.5 \mathrm{M}$ sodium phosphate buffer ( $\mathrm{pH} 7.2$ ). Filters were hybridized with PML cDNA insert radiolabelled by the random priming method. A partial cDNA probe for PML w as synthesized by RT-PCR from total RNA of THP1 cells using primers S1: 5'-ACCAGTCGGTGCGTGAGTT-3' and AS1: 5'-TGGATCTCTGCGCTGATGTC-3', corresponding to nucleotides 525-544 and 715-734, respectively of the published sequence. ${ }^{13}$ This part of the PML sequence is $100 \%$ homologous for all PML genes. The synthesized cDNA was controlled by DNA-sequencing and $w$ as subcloned into pCRTM II using a commercial cloning kit (Invitrogen, Leek, Netherlands). For quantitative analysis of mRNA levels densitometric scanning of autoradiographs was applied by using the Quanti-scan ${ }^{\circledR}$ program. PML-specific transcript levels were normalized to $\beta$-actin mRNA expression.

\section{Immunofluorescence analysis}

Quantitative immunofluorescence studies of PML expression were performed by flow cytometry (EPICS, Coulter, Germany) as described ${ }^{11}$ by using saturating concentrations of a PML specific mAb. ${ }^{14}$ Normal mouse IgG $(2 \mu \mathrm{g} / \mathrm{ml})$ (Coulter, Krefeld, Ger- many) was used as background control, and FITClabelled goat-anti-mouse IgG (Coulter, Krefeld, Germany) as second reagent. A total of 50000 cells was analysed for each determination and specific fluorescence intensity was calculated on the basis of background fluorescence with control antibodies by using the EPICS program. Mean specific fluorescence intensity is given as channel number on a log scale from 1 to 1024 or in percentage of the respective untreated control.

\section{Indirect immunofluorescence microscopy}

Cells were air dryed overnight, fixed for $5 \mathrm{~min}$ with aceton followed by incubation with PG-M3 antibody ${ }^{14}$ as undiluted hybridoma supernatant or with normal mouse IgG (Coulter, Krefeld, Germany) at a concentration of $2 \mu \mathrm{g} / \mathrm{ml}$ for $5 \mathrm{~min}$. Cells were then washed with PBS and incubated $w$ ith a FITC labelled goat-antimouse antibody (Coulter, Krefeld, Germany) $(5 \mu \mathrm{g} / \mathrm{ml})$. Cells were analysed with a fluorescence microscope (Orthoplan, Leitz, Wetzlar, Germany).

\section{Results}

\section{PML mRNA levels are upregulated by type I and type II interferons}

To investigate whether IFN affects PML gene expression, we performed Northern blot analyses of total cellular RNA extracted from various hae matopoietic cell lines cultured with and without IFNs. In all cell types tested including the myeloid cell lines HL60 and THP1, human diploid fibroblasts and human peripheral blood mononuclear cells a marked increase in the three major PML transcript levels was observed by treatment with both type I $(\alpha, \beta)$ and type II $(\gamma)$ interferons (Figs 1-4). Dose response experiments

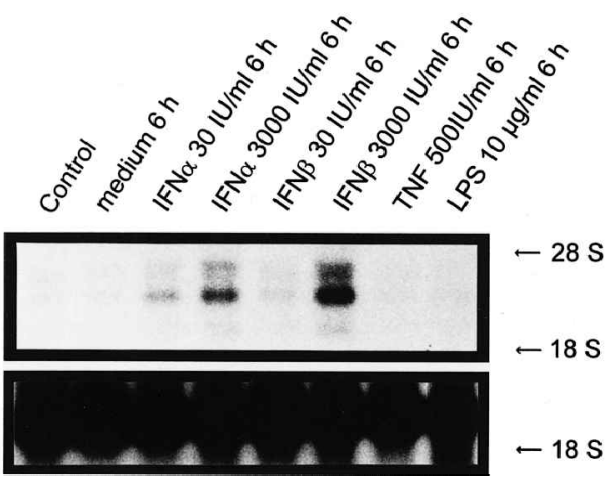

FIG. 1. Induction of PML mRNA by interferon. Northern blot analysis of PML-specific mRNA levels from IFN-treated and untreated PBMNC. PBMNC were treated with the indicated dose of IFN- $\alpha$, IFN- $\beta$, TNF- $\alpha$ or LPS for $6 \mathrm{~h}$. Medium treated PBMNC and freshly isolated PBMNC without further incubation were included as controls. Size fractionated total cellular RNA (20 $\mu \mathrm{g}$ per lane) was blotted and hybridized to the indicated ${ }^{32}$ P-labelled cDNA probes. For quantitative analysis of mRNA levels densitometric scanning of autoradiographs was applied as described in Materials and Methods. 


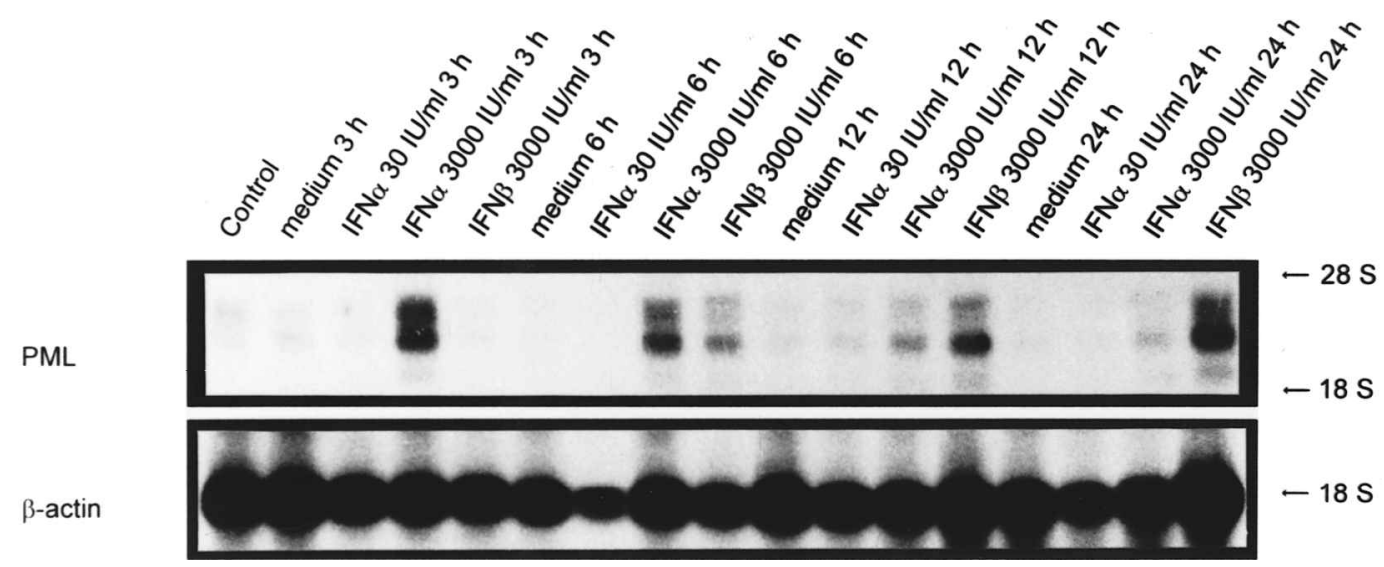

FIG. 2. Time-response of induction of PML mRNA by IFN- $\alpha$ and IFN- $\beta$. Northern blot analy sis of PML-specific mRNA levels from IFN-treated and untreated PBMNC. PBMNC were treated with the indicated dose of IFN- $\alpha$ and IFN- $\beta$ for the indicated time. Medium-treated PBMNC and freshly isolated PBMNC without further incubation were included as controls. Size fractionated total cellular RNA ( $20 \mu \mathrm{g}$ per lane) was blotted and hybridized to the indicated ${ }^{32} \mathrm{P}$-labelled cDNA probes.

showed that upregulation of PML mRNA levels was already evident upon incubation with $30 \mathrm{IU} / \mathrm{ml} \mathrm{IFN}-\alpha$ for $6 \mathrm{~h}$ (Fig. 1). At IFNa doses of $30 \mathrm{IU} / \mathrm{ml}$ and $3000 \mathrm{IU} /$ $\mathrm{ml}$, quantitative analysis employing densitometric scanning revealed a 3.2 -fold and a 5.3 -fold induction of PML mRNA levels, respectively (Fig. 1). As a control, PML transcrip t levels were monitored upon incubation for $6 \mathrm{~h}$ with TNF- $\alpha$ and LPS and were found to be unchanged (Fig. 1). In ex periments (Fig. 2 and data not shown) investigating the kinetics of IFN- $\alpha$ induced PML mRNA upregulation in PBMNC, maximum enhancement of PML transcript expression was already observed upon incubation for $3 \mathrm{~h}(3000 \mathrm{IU} / \mathrm{ml}$ IFN- $\alpha$ ). The reafter PML transcript levels declined and were barely visible after $24 \mathrm{~h}$ despite continuous

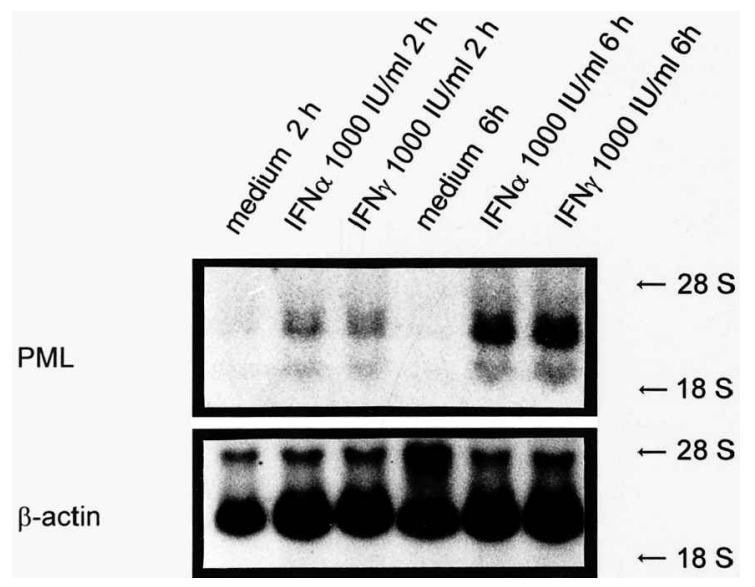

FIG. 3. Northern blot analysis of PML-specific mRNA levels from IFN- $\alpha$ and IFN- $\gamma$ treated HL60 cells. HL60 cells were treated with IFN- $\alpha(1000 \mathrm{IU} / \mathrm{ml})$ or IFN- $\gamma(1000 \mathrm{U} / \mathrm{ml})$ for the indicated time or were left untreated. Northern blotting was performed as described above. Densitometric scanning revealed a 2.5-fold and 1.9-fold induction of PML-mRNA levels upon incubation for $2 \mathrm{~h}$ with IFN- $\alpha(1000 \mathrm{IU} / \mathrm{ml})$ and IFN- $\gamma(1000 \mathrm{IU} / \mathrm{ml})$, respectively. Incubation for $6 \mathrm{~h}$ with IFN- $\alpha$ $(1000 \mathrm{lU} / \mathrm{ml})$ and $\mathrm{IFN}-\gamma(1000 \mathrm{lU} / \mathrm{ml})$ showed a 25.4 -fold and a 27.4-fold induction of PML-specific transcript levels. incubation with $3000 \mathrm{IU} / \mathrm{ml}$ IFN- $\alpha$ (Fig. 2). In contrast to IFN- $\alpha$, IFN- $\beta$ ( $3000 \mathrm{IU} / \mathrm{ml})$ induced PML transcript induction increased gradually over time and maximum enhancement was reached at $24 \mathrm{~h}$ (Fig. 2). The time course of IFN- $\gamma$ induced PML transcript enhancement during a 6-h-incubation period was similar to IFN- $\alpha$ (Fig. 3). Previous studies indicated that transcriptional regulation of the PMLgene is involved in up-regulation of PML mRNA by IFNs. ${ }^{15,16}$ To confirm that IFNinduced modulation of PML mRNA is independent from de novo protein synthesis, we performed

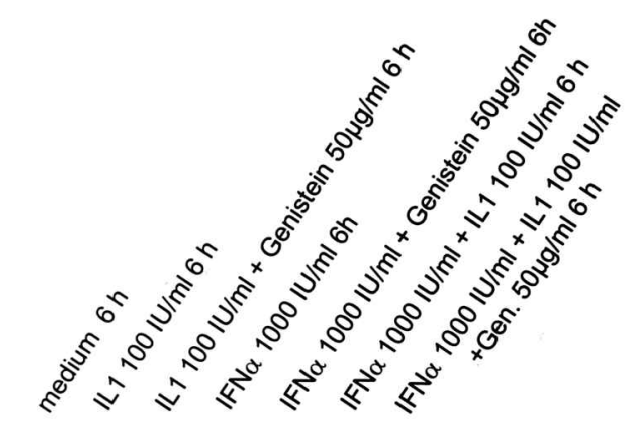

PML

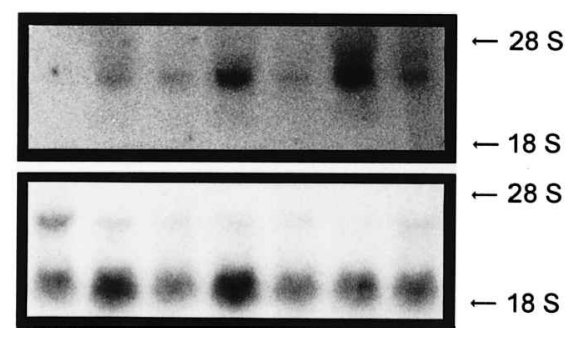

FIG. 4. Induction of PML-specific mRNA by IL- $1 \alpha$ and IFN- $\alpha$. Human diploid foreskin fibroblasts were treated with IL-1 $\alpha$ $(100 \mathrm{lU} / \mathrm{ml})$, with $\mathrm{IFN}-\alpha(1000 \mathrm{lU} / \mathrm{ml})$ or with a combination of IFN- $\alpha(1000 \mathrm{lU} / \mathrm{ml})$ and $\mathrm{IL}-1 \alpha(100 \mathrm{lU} / \mathrm{ml})$ for $6 \mathrm{~h}$. Cells were grown in the absence or presence of an inhibitor of protein tyrosine kinases (genistein $50 \mu \mathrm{g} / \mathrm{ml}$ ). Northern blotting was performed as described above. For quantitative analysis, PML-specific transcript levels were analysed by densitometric scanning and normalized to $\beta$-actin mRNA expression as described in Materials and Methods. 
Northern blot analyses with and without an inhibitor of protein synthesis (CHX). These ex periments demonstrated that CHX had no effect on IFN-induced up regulation of PML mRNA (data not show $\mathrm{n}$ ).

The influence of IL- $1 \alpha$ on PML transcript expression was investigated in human foreskin fibroblasts (Fig. 4). Treatment with IL- $1 \alpha$ at a dose of $100 \mathrm{IU} / \mathrm{ml}$ for $6 \mathrm{~h}$ resulted in a 3.8 -fold upregulation of PMLspecific mRNA levels as analysed by densitometric scanning. A more pronounced enhancement of PML transcript levels (7.1-fold induction) was observed when cells were incubated with IFN- $\alpha$. IL-1 in combination with IFN- $\alpha$ stimulated PML mRNA expression to more than twice the level obtained with IFN- $\alpha$ alone ( 15.3 fold induction relative to medium control), as estimated by densitometric scanning. Coincubation with genistein, ${ }^{17}$ an inhibitor of tyrosine kinases, significantly inhibited the IFN-induced increase in the level of PML transcripts, whereas no effect of genistein on IL-1 induced PML mRNA expression was noted (Fig. 4). Similar results were obtained using the amnion fibroblast cell line WISH (data not shown).

\section{Influence of IFN- $\alpha$ on PML protein expression}

In an attempt to investigate modulation of PLM protein expression, we performed flow cytometry

A:

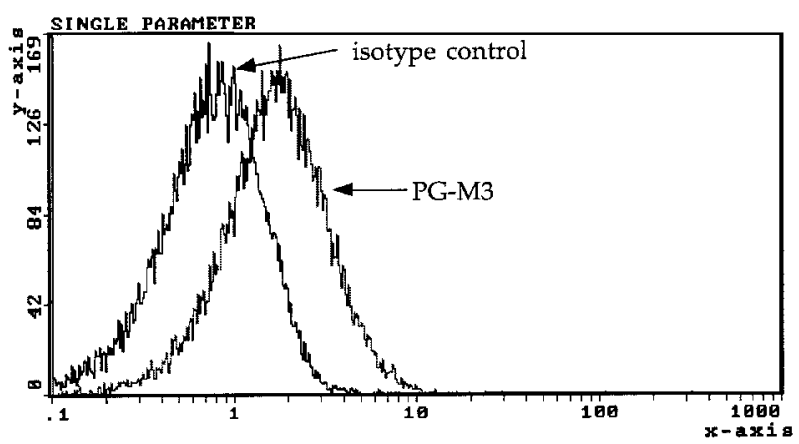

B:

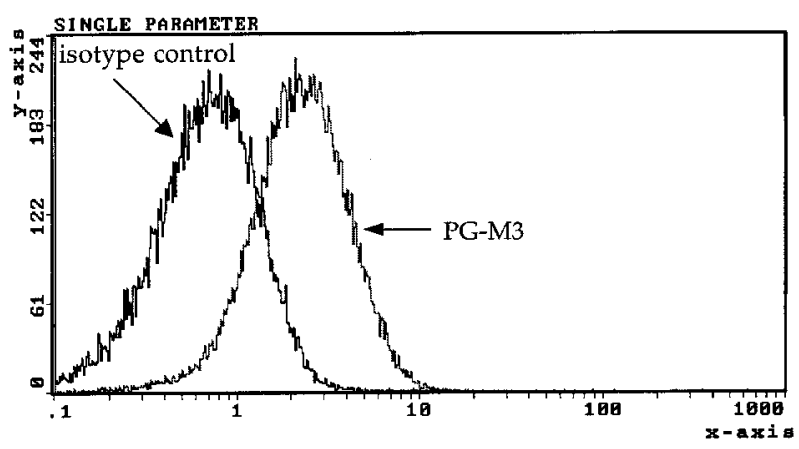

FIG. 5. Induction of PML protein by IFN- $\alpha$ in HL60 cells. HL60 cells were treated with (B) and without (A) IFN- $\alpha(1000 \mathrm{lU} / \mathrm{ml})$ for $18 \mathrm{~h}$. Expression of PML protein was analysed by flow cytometry using a specific monoclonal anti-PML antibody as descibed in Materials and Methods. Normal mouse lgG was used as isotype control.
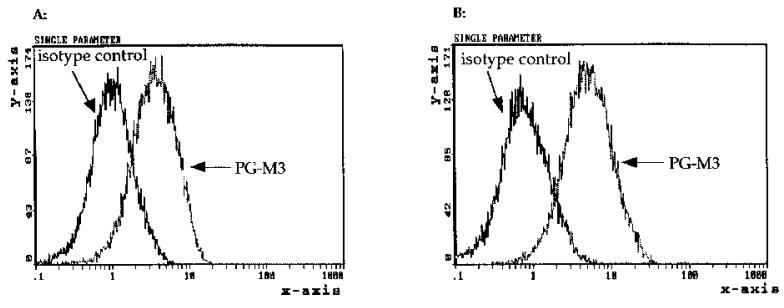

\begin{tabular}{c|c|c|c|c|c} 
time (1000 IU IFN $\alpha)$ & med. (A:) & $6 \mathbf{h}$ & $12 \mathrm{~h}$ & $16 \mathrm{~h}$ & $19,5 \mathbf{h ~ ( B : )}$ \\
\hline AMeanX & 2,5 & 2,4 & 2,5 & 3,8 & 4,3
\end{tabular}

FIG. 6. Kinetics of induction of PML protein by IFN- $\alpha$ in U937 cells. U937 cells were treated with and without IFN- $\alpha$ $(1000 \mathrm{lU} / \mathrm{ml})$ for the indicated time (A: medium control; $\mathrm{B}$ : IFN- $\alpha$ for 19.5h). Induction of PML protein was monitored by flow cytometry using a specific monoclonal antibody recognizing the aminoterminal domain of PML as described in Materials and Methods. Normal mouse lgG was used as isotype control. Given is the mean log specific fluorescence intensity as described in Materials and Methods.

analyses. IFN- $\alpha$ treatment of the three myeloid cell lines HL60, NB4 and U937 resulted in upregulation of PML protein expression. For example, in HL60 cells, upregulation of PML expression was detectable upon incubation with IFN- $\alpha$ for $18 \mathrm{~h}$ (Fig. 5). The time course of IFN-induced enhancement of PML protein expression was monitored in U937 cells (Fig. 6). Induction of PML was not de tectable upon incubation with IFN- $\alpha(1000 \mathrm{IU} / \mathrm{ml})$ for only $6 \mathrm{~h}$ or $12 \mathrm{~h}$ but started thereafter and reached a plateau at $20 \mathrm{~h}$ (Fig. 6 and data not shown). Dose-response experiments in U937 cells revealed that incubation with $10 \mathrm{U} / \mathrm{ml} \mathrm{IFN-}$ $\alpha$ for $20 \mathrm{~h}$ already resulted in slight upregulation of PML protein expression to $113 \%$ of the untreated control (Fig. 7). Maximum upregulation of PML expression to $160 \%$ of that of untreated cells was achieved by incubation with doses greater than $500 \mathrm{IU} / \mathrm{ml} \mathrm{IFN}-\alpha$ (Fig. 7). These data indicate that half-

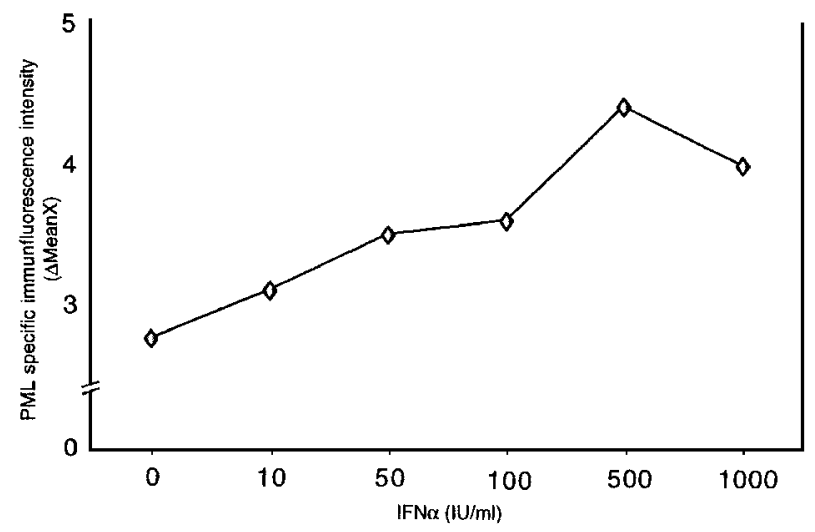

FIG. 7. Dose-response of induction of PML protein by IFN- $\alpha$ in U937 cells. U937 cells were incubated for $18 \mathrm{~h}$ in the absence or presence of the indicated dose of IFN- $\alpha$ and PML protein expression was analysed by flow cytometry using a specific monoclonal antibody as described in Materials and Methods. Given is the mean log specific fluorescence intensity as described in Materials and Methods. 
Table 1. Induction of $\mathrm{PML}$ protein by $\mathrm{IFN}-\alpha, \mathrm{IL}-1 \alpha$ or a combination of both in human diploid fibroblasts

\begin{tabular}{|c|c|c|}
\hline Treatment & $\stackrel{\Delta}{\text { Mean } X}$ & $\begin{array}{c}x \text {-fold } \\
\text { induction }\end{array}$ \\
\hline $\begin{array}{l}\text { Medium } \\
\text { IFN- } \alpha(100 \mid \mathrm{U} / \mathrm{ml}) \\
\text { IL-1 } \alpha(100 \mid \mathrm{U} / \mathrm{ml}) \\
\text { IL-1 } \alpha(1000 \mid \mathrm{U} / \mathrm{ml}) \\
\text { IFN- } \alpha(100 \mid \mathrm{U} / \mathrm{ml})+\mathrm{IL}-1 \alpha(100 \mid \mathrm{U} / \mathrm{ml}) \\
\text { IFN- } \alpha(100 \mid \mathrm{U} / \mathrm{ml})+\mid \mathrm{L}-1 \alpha(1000 \mid \mathrm{U} / \mathrm{ml})\end{array}$ & $\begin{array}{l}1.29 \\
2.75 \\
2.31 \\
2.43 \\
4.30 \\
3.80\end{array}$ & $\begin{array}{l}1.0 \\
2.1 \\
1.8 \\
1.9 \\
3.3 \\
3.0\end{array}$ \\
\hline
\end{tabular}

Fibroblasts were incubated with and without the indicated cytokines at the indicated dose for $21.5 \mathrm{~h}$. Induction of PML protein expression was analysed by flow cytometry using a specific anti-PML monoclonal mouse antibody and normal mouse $\lg \mathrm{G}$ as control as described above. Given is the mean log specific fluorescence intensity as described in Materials and Methods.

maximum IFN- $\alpha$ response is reached at $50 \mathrm{U} / \mathrm{ml}$ IFN- $\alpha$ which corresponds to the IFN- $\alpha$ concentration needed to achieve a half-maximum response in other biological activities of IFN- $\alpha{ }^{10}$

When human foreskin fibroblasts were grow $\mathrm{n}$ in the absence or or in the presence of saturating concentrations of IL-1 $\alpha$, a nearly two-fold increase of PML protein expression was detected by flow cytometry analysis (Table 1). A similar result was obtained upon incubation with IFN- $\alpha(100 \mathrm{IU} / \mathrm{ml})$. The combination of IL-1 and IFN- $\alpha$ stimulated PML protein expression to about three times the level observed in untreated controls (Table 1).

\section{Analysis of PML nuclear bodies}

Since it has been show $\mathrm{n}$ that PML proteins are located within subnuclear structures from active sites of transcription and splicing, the so-called PML nuclear bodies were monitored during IFN- $\alpha$ treatment using indirect immunofluorescence staining. PML-specific immunofluorescence varied in intensity between the

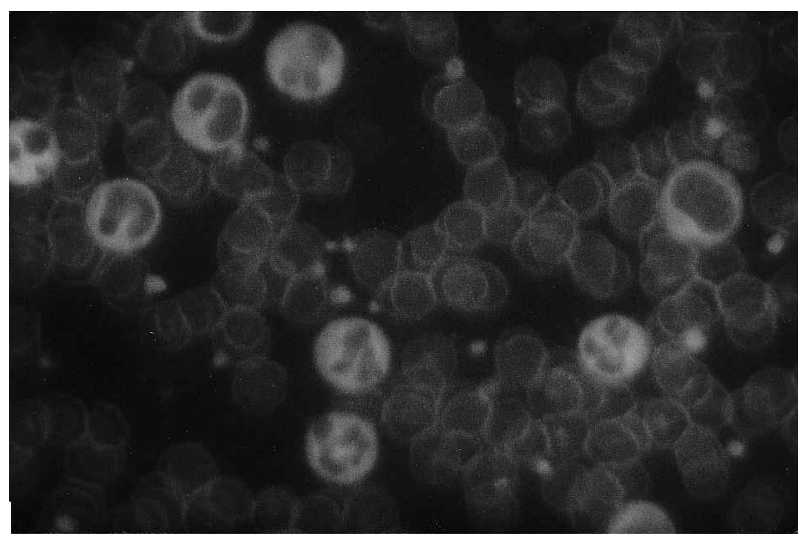

(A) cell lines tested. In all cell lines tested (NB4, HL60, U937) and in peripheral blood leukocytes the constitutive levels of endogenous proteins were detectable (Figs 8 and 9). Peripheral blood leukocytes revealed specific immunolabelling of PML nuclear bodies in neutrophils and monocytes (Fig. 8). When HL60 and U937 cells were incubated for $15 \mathrm{~h}$ with and without IFN- $\alpha(1000 \mathrm{U} / \mathrm{ml})$ a marked enhancement of the immunolabelling was observed in treated cells. Both the intensity of the staining and the number of the labelled PML nuclear bodies was increased significantly (Fig. 9 and data not shown).

\section{Discussion}

Our data confirm and extend previous studies demonstrating that cytokines are involved in modulation of PML gene expression. ${ }^{15,16}$ We show that PML transcripts rapidly accumulate upon treatment with interferons in a variety of haematopoietic cell lines and in primary diploid cells. However, our experiments demonstrate a marked difference in the time course of PML-mRNA induction between IFN- $\alpha$ and IFN- $\beta$. Induction of PML in response to IFN was shown to be independent from de novo protein synthesis and actinomycin sensitive indicating that PML mRNA levels are transcriptionally regulated by IFNs. ${ }^{16}$ Recently, evidence has been provided that the PML gene is transcriptionally upregulated by IFNs through activation and binding of STATs to an ISRE and a GAS element in the untranslated first exon. ${ }^{18}$ IFNs activate STATS through tyrosine phosphorylation by members of the JAK tyrosine kinase family. ${ }^{19}$ Our results demonstrating inhibition of IFN-induced upregulation of PML transcripts by the tyrosine kinase inhibitor genistein are consistent with these findings. Flow cytometry analyses using a specific monoclonal anti-PML antibody recognizing the aminoterminal domain clearly demonstrate that IFNs induce PML

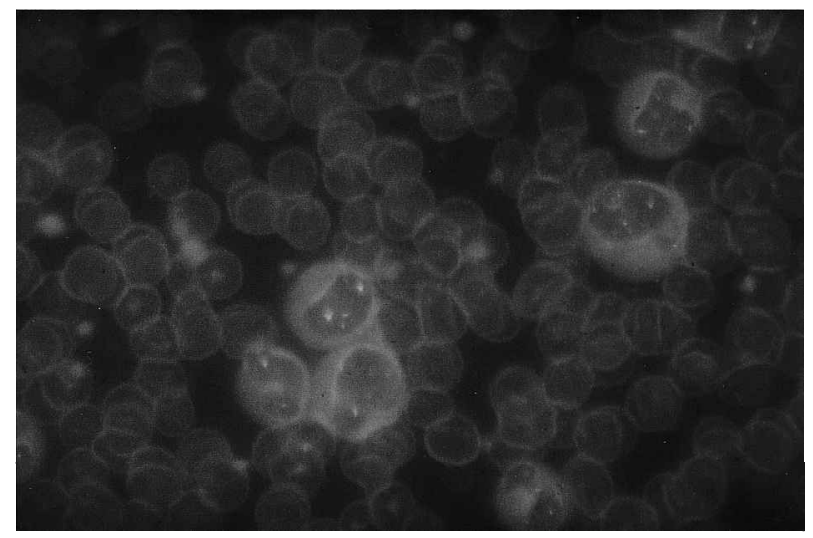

(B)

FIG. 8. In situ immunofluorescence analysis of PML proteins in human peripheral blood leukocytes. Indirect immunofluorescence analysis of a peripheral blood smear was performed using the specific mouse monoclonal antibody PG-M3 (B) and normal mouse lgG (A) as control as described in Materials and Methods. Specific immunolabelling can be detected in neutrophils and monocytes which were identified by morphologic criteria. 


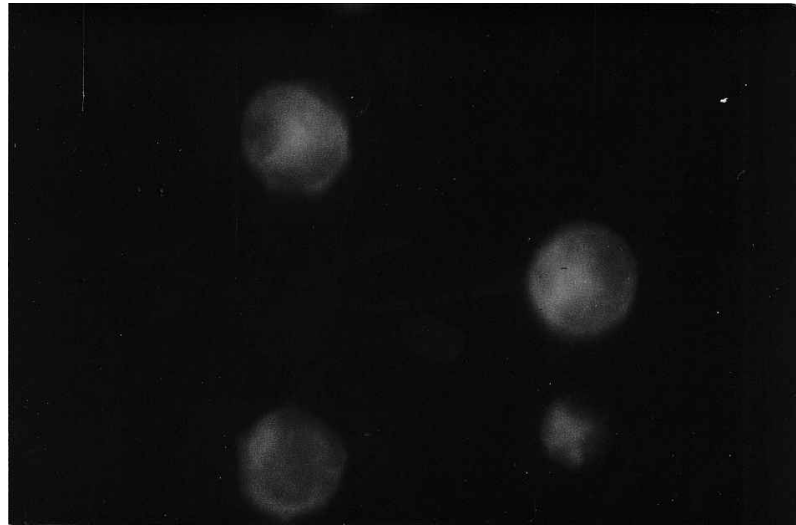

(A)

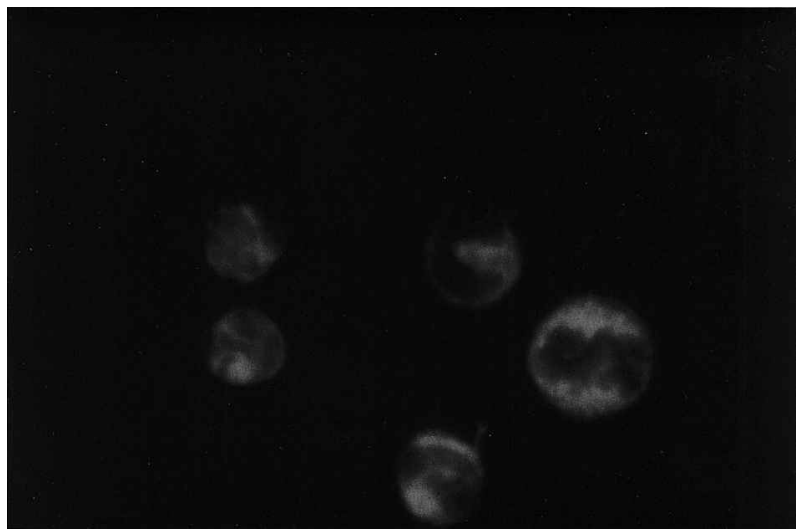

(C)

FIG. 9. In situ immunofluorescence analysis of PLM proteins in HL60 cells. HL60 cells were incubated with (C, D) and without (A, B) IFN- $\alpha(1000 \mathrm{lU} / \mathrm{ml})$ for $15 \mathrm{~h}$. Indirect immunofluorescence analysis was performed using the specific mouse monoclonal antibody PG-M3 $(B, D)$ and normal mouse lgG $(A, C)$ as control as described in Materials and Methods.

protein in a dose dependent manner. Recently, it has been shown that PML protein expression has a speckled nuclear pattern. ${ }^{15}$ This is due to localization of the protein in poorly defined nuclear organelles named nuclear bodies. The functions of the nuclear bodies are unknown except for the coiled bodies which act as storage compartments for splicing factors. $^{20}$ To analyse expression of PML proteins within nuclear bodies we performed indirect in situ immunofluorescence studies. In situ immunolabelling of PML protein expression revealed an IFNinduced increase in number and intensity of so-called PML nuclear bodies.

To the best of our knowledge induction of PML by IL-1 has not been described so far. Here we show that IL-1 $\alpha$ rapidly induces PML mRNA expression in fibroblasts. Since IL-1 is a potent inducer of IFN- $\alpha$ and IFN- $\beta^{21}$ it could be argued that the observed induction of PML mRNA expression is a consequence of IL1 induced autocrine production of interferon- $\beta$. We addressed this issue by employing the tyrosine kinase inhibitor genistein. Genistein was show $n$ to strongly inhibit IFN signalling. ${ }^{17}$ Our experiments clearly show that in fibroblasts genistein is not able to suppress the IL-1 induced upregulation of PML

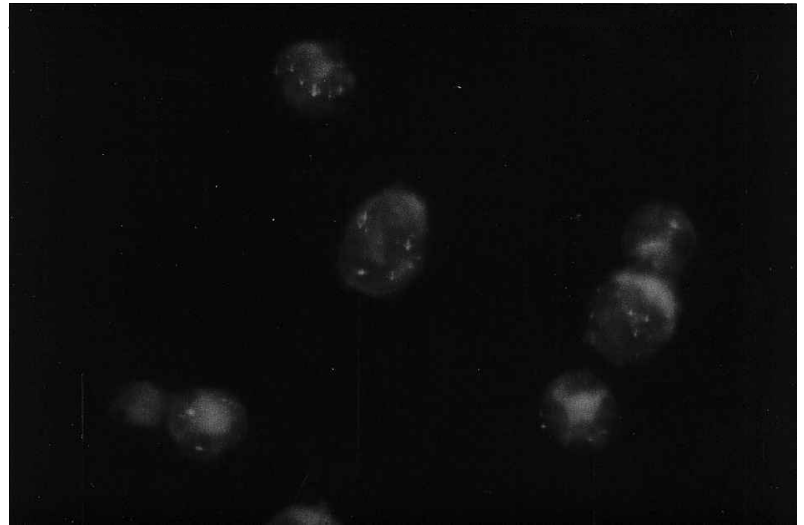

(B)

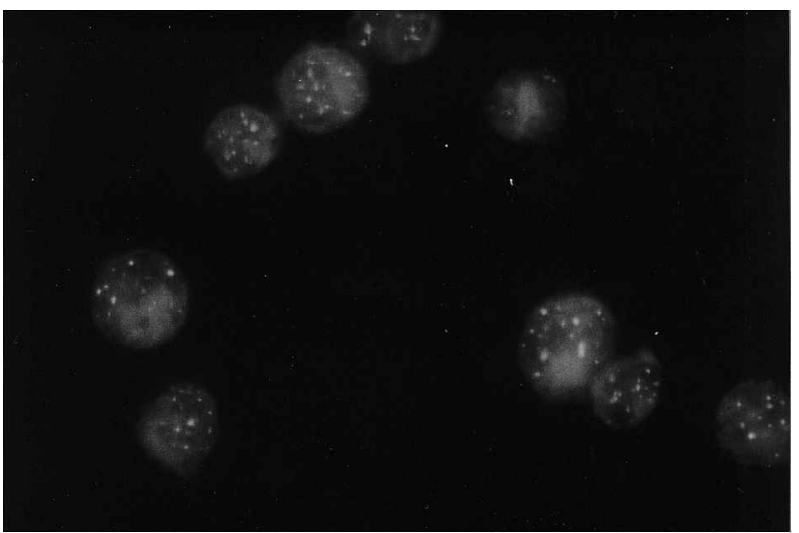

(D) transcripts, whereas IFN-induced enhancement of PML-specific transcripts was strongly inhibited. Thus, indirect regulation of PML by IL-1 induced autocrine production of IFN- $\beta$ ap pears unlikely. Flow cytometry analys is revealed that IL- 1 and IFN- $\alpha$ act synergistically in induction of PML proteins. This regulation could be involved in the observed upregulation of PML prote ins in inflammation. In contrast to normal tissues, in inflammatory tissues the level of PML proteins is upregulated. $^{7,8}$ Local production of IL-1 has been demonstrated in inflammatory and autoimmune disease and this may contribute to tissue damage and repair. $^{21,22}$ In fibroblasts, IL-1 mediates tissue repair after inflammation and injury by regulating key proteins necessary for formation of the extracellular matrix..$^{21,22}$ The data presented here suggest that IL-1 induced PML expression may represent the molecular basis for the observed upregulation of PML proteins during inflammation. IFNs, as part of the cytokine network are indirectly induced by regulators such as tumour necrosis factor during immune responses and inflammation. This may contribute to upregulation of PML in inflammatory tissues by synergistic action of IFN- $\alpha$ and IL-1 in enhancing PML protein expression in fibroblasts.

\section{ivediators or lintammation. Vol 1.298}




\section{References}

1. Grignani F, Ferrucci PF, Testa U, et al. The acute promyelocytic leukemiaspecific PML-RAR $\alpha$ fusion protein inhibits differentiation and promotes survival of myeloid precursor cells. Cell 1993; 74: 423-431.

2. Daniel MT, Koken M, Romagné O, et al. PML protein expression in hematopoietic and acute promyelocytic le ukemia cells. Blood 1993; 82: $1858-1867$.

3. Kakizuka A, Miller Jr WH, Umesono K, et al. Chromosomal translocation $\mathrm{t}(15 ; 17)$ in human acute promyelocytic leukemia fuses RAR $\alpha$ with a novel putative transcription factor, PML. Cell 1991; 66: 663-674.

4. Mu ZM, Chin KV, Liu JH, Lozano G, Chang KS. PML, a grow th suppressor disrupted in acute promyelocytic leukemia. Mol Cell Biol 1994; 14: 6858-6867.

5. Fagioli $M$, et al. Alternative splicing of PML transcripts predicts coexpression of several carboxy-terminally different protein isoforms. Oncogene 1992; 7: 1083-1091.

6. Wang ZG, Delva L, Gaboli M, et al. Role of PML in cell grow th and the retinoic acid pathway. Science 1998; 279: 1547-1551.

7. Terris B, Baldin V, Dubois S, et al. PML nucle ar bodies are general targets for inflammation and cell proliferation. Cancer Res 1995; 55: $1590-1597$.

8. Gambocorta M, Flenghi L, Fagioli M, et al. Heterogeneous nuclear expression of the promyelocytic leukemia (PML) prote in in normal and neoplastic human tissues. Am J Pathol 1996; 149: 2023-20035.

9. Koken MHM, Linares-Cruz G, Quignon F, et al. The PML grow thsuppressor has an altered expression in human oncogenesis. Oncogene 1995; 10: 1315-1324.

10. Sen GC, Lengyel P. The interferon system. J Biol Chem 1992; 267: $5017-$ 5020 .

11. Fischer T, Wiegmann K, Böttinger H, Morens K, Burmester G, Pfizenmaier K. Regulation of IFN- $\gamma$-receptor expression in human monocytes by granulocyte-macrophage colony-stimulating factor. J Immunol 1990; 145: $2914-2919$.

12. Chomczynski P, Sacchi N. Single step method of RNA isolation by guanidinium thiocyanate-phenol-chloroform extraction. Anal Biochem 1987; 162: 156-159.
13. Goddard AD, Borrow J, Freemont PS, Solomon E. Characterization of a zinc finger gene disrupted by the $\mathrm{t}(15 ; 17)$ in acute promyelocytic leukemia. Science 1991; 254: 1371-1374.

14. Flenghi L, Fagioli M, Tomassoni L, et al. Characterization of a new monoclonal antibody (PG-M3) directed against the aminoterminal portion of the PML gene product: immunocytochemical evidence for high expression of PML proteins on activated macrophages, endothelial cells, and epithelia. Blood 1995; 7: 1871-1880.

15. Chelbi-Alix MK, Pelicano L, Quignon F, et al. Induction of the PML protein by interferons in normal and APL cells. Leuke mia 1995; 9: 2027-2033.

16. Lavau C, Marchio A, Fagioli M, et al. The acute promyelocytic leukemiaassociated PML gene is induced by interferon. Oncogene 1995; 11: $871-876$.

17. David M, Romero G, Zhang ZY, Dix on JE, Larner AC. In vitro activation of the transcription factor ISGF3 by interferon- $\alpha$ involves a membraneassociated tyrosine phosphatase and tyrosine kinase. J Biol Chem 1993; 268: 6593-6599.

18. Stadler M, Chelbi-Alix MK, Koken MHM, et al. Transcriptional induction of the PML grow th suppressor gene by interferons is mediated through an ISRE and a GAS element. Oncogene 1995; 11: 2565-2573.

19. Ransohoff RM. Cellular responses to interferons and other cytokines: the JAK-STAT paradigm. N Engl J Med 1998; 338: 616-618.

20. Visa $N$, et al. Intranuclear distribution of poly A RNA determined by electron microscopy in situ hybridization. Exp Cell Res 1993; 208: $19-34$.

21. Balkwill FR. The other interleukins. In: Balkwill FR. Cytokines in Cancer Thera py. Ox ford: Ox ford University Press, 1989; 150-182.

22. Dinarello CA. Biologic basis for interleukin-1 in disease. Blood 1996; 87: 2095-2147

ACKNOWLEDGEMENTS. This work was supported by Grant 405/1-4 from the German Research Council (Deutsche Forschungsgemeinschaft). This work is in partial fulfilment of M.H.' 'Medical Thesis'.

\section{Received 8 June 1998;} accepted in revised form 23 July 1998 


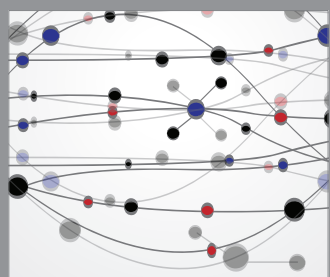

The Scientific World Journal
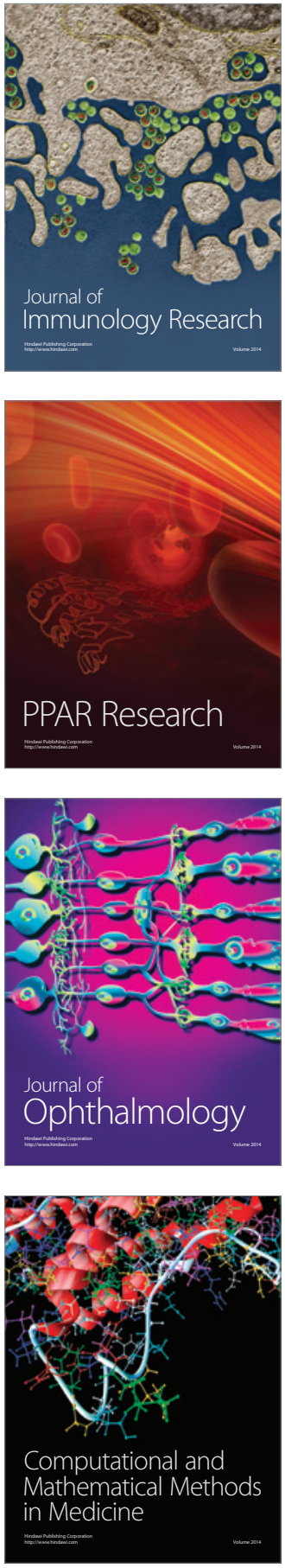

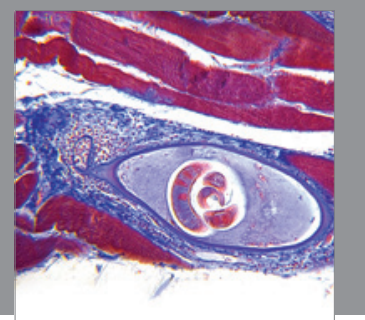

Gastroenterology

Research and Practice
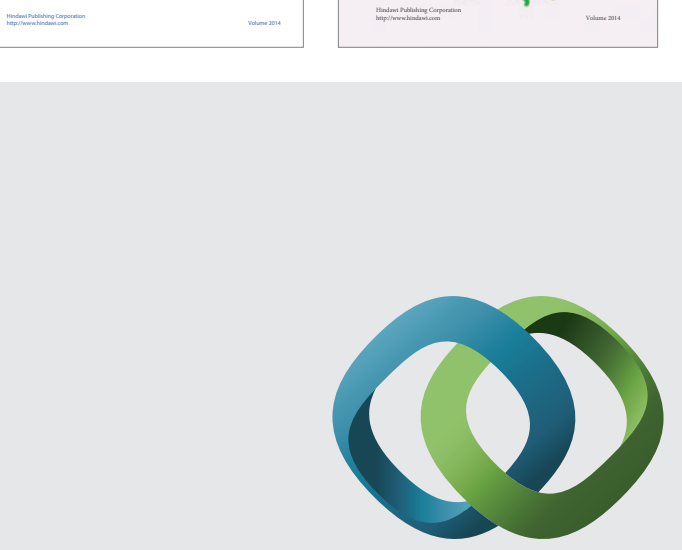

\section{Hindawi}

Submit your manuscripts at

http://www.hindawi.com
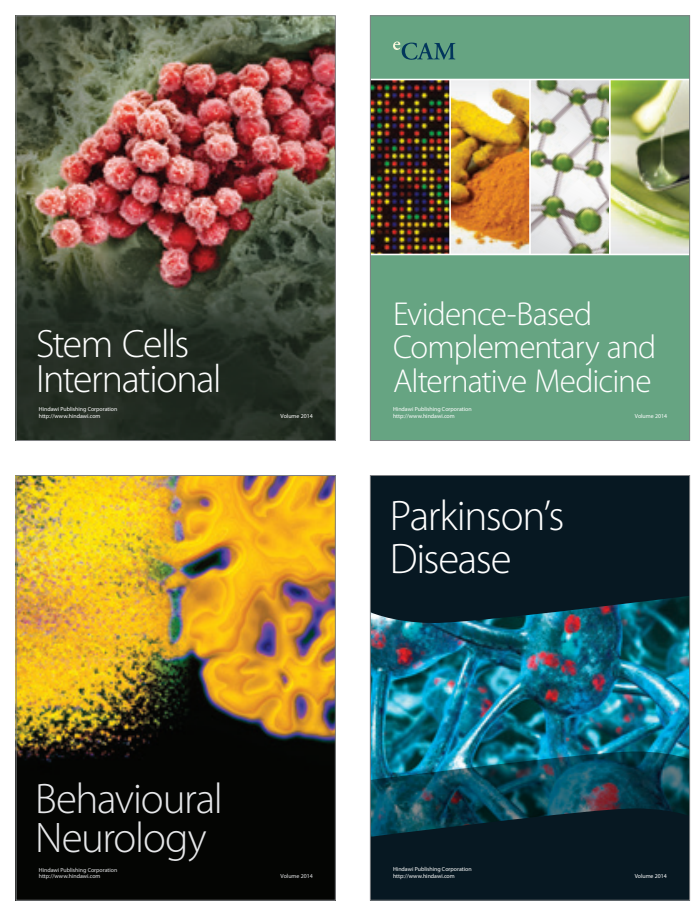

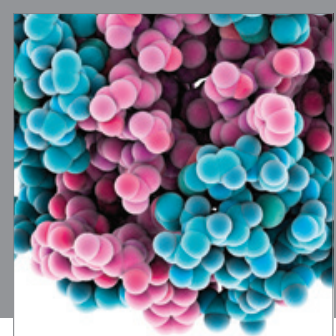

Journal of
Diabetes Research

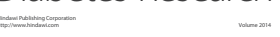

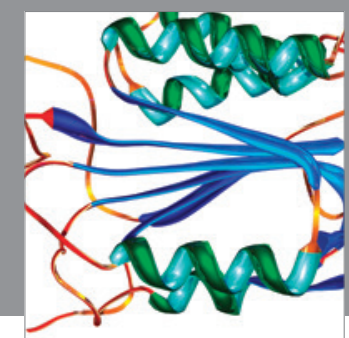

Disease Markers
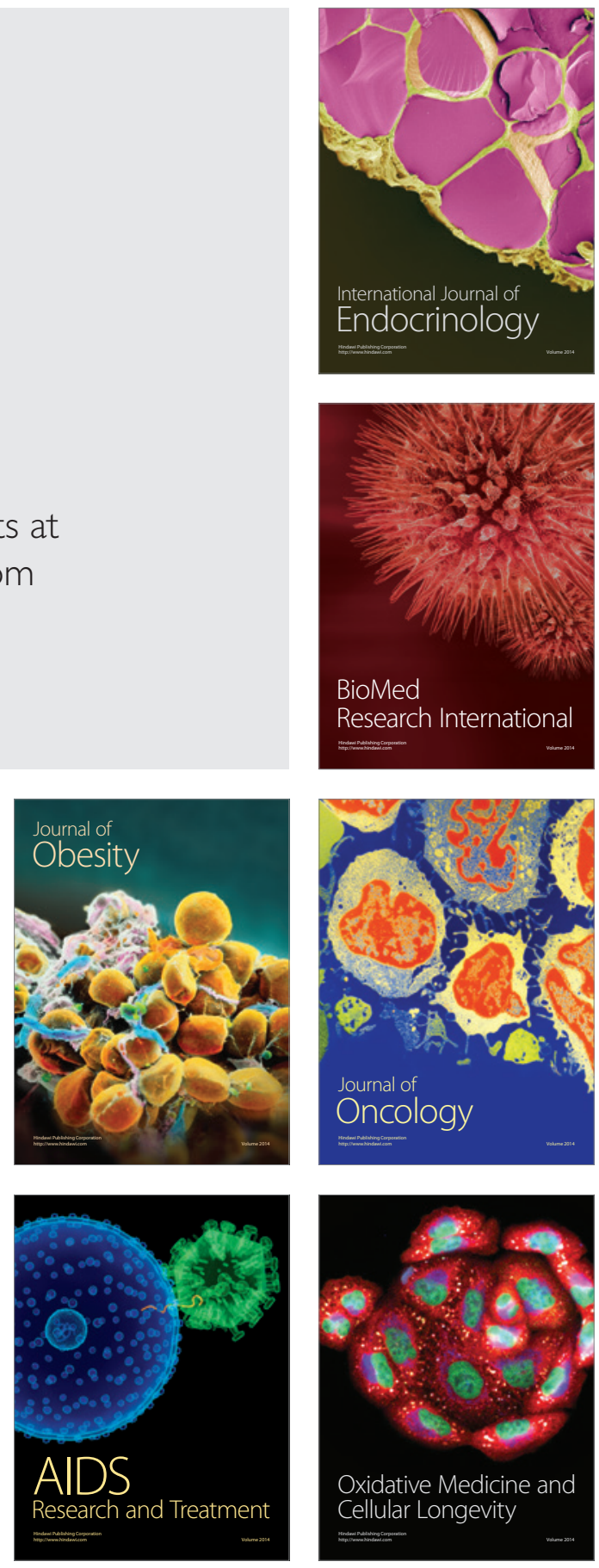